\title{
Effects of watering after lifting and exposure before planting on plant quality and performance in Oriental spruce
}

\author{
M Genç \\ Department of Silviculture, Faculty of Forestry, Karadeniz Technical University, \\ Trabzon 61080, Turkey
}

(Received 22 December 1994; accepted 31 May 1995)

\begin{abstract}
Summary - Four-year-old transplants of Oriental spruce (Picea orientalis $(\mathrm{L})$ Link) were lifted on 28 March 1990, 30 March 1990 and 2 April 1990 during the postdormancy phase. Some of them were then watered immediately, and all of the seedlings, watered and unwatered, were kept in moist conditions within cloth sacks. A part of the watered transplants were planted immediately, whereas the others were planted after $60 \mathrm{~min}$ exposure. However, the unwatered transplants were subjected to drought on the ground for $0,15,30$ and 60 min. Plants with 60 min exposure were watered before planting only. After treatments, shoot water potentials were measured using the pressure chamber technique. Best water potential, survival and growth were obtained from transplants watered after lifting. In these seedlings, exposure particularly stimulated root growth. With unwatered transplants, however, both water potential and relative increment of height or dry weight declined significantly as exposure time prolonged, but survival and rate of terminal shoots reduced only slightly.
\end{abstract}

\section{Picea orientalis / watering / exposure / shoot water potential / seedling performance}

Résumé - Effets de mouillage et de l'exposition à l'air avant transplantation, sur la qualité et les performances de plants d'épicéa oriental. Les plants d'épicéa oriental repiqués à 4 ans sont arrachés pendant la période post-dormance et mouillés ou non immédiatement, puis protégés dans des sacs humides. Une partie des plants mouillés sont plantés dans l'état où ils se trouvent, les autres sont d'abord laissés à l'air libre pendant 60 minutes puis sont plantés. D'autre part, les plants non mouillés sont laissés à l'air libre pendant 0,15 et 30 minutes ou bien sont exposés à l'air libre 60 minutes et mouillés avant plantation. Les potentiels hydriques des pousses sont mesurés après les traitements par la technique de la chambre de pression. La survie et la croissance des plants sont mesurées à la fin de la saison de croissance. Le potentiel est hydrique, la survie et la croissance sont meilleures pour les plantes mouillées avant transplantation. Chez ces plants l'exposition à l'air a stimulé la croissance des racines. Cependant, chez les plants non mouillés, potentiel hydrique et croissance relative ou poids sec des plants ont diminué significativement en fonction du temps d'exposition à l'air, mais la survie et la proportion des pousses terminales ont diminué légèrement.

Picea orientalis / exposition à l'air / stress hydrique / performance des plants 


\section{INTRODUCTION}

Rough handling or root and/or shoot exposure to ambient conditions before planting are very important for seedling performance, because these treatments directly affect water relations and root growth capacity of stocks and increase mortality. Sharpe et al (1990) found in the 2-year-old undercut or transplanted stocks of Sitka spruce and Douglas fir that rough handling lowered root growth capacity as well as survival. Balneaves (1987) determined in macrocarpa (Cupresus macrocarpa) and radiata pine that water potential in both species declined with increased periods of root exposure. The same results were also given by Coutts (1981) for Sitka spruce. In another study, Menzies (1981) emphasized that water dipping radiata pine seedlings after exposure and just before planting decreased mortality. In radiata pine seedlings, therefore, water dipping after lifting and again before planting is recommended.

These investigations are necessary to ensure successful outplanting. However, such a study has not yet been realized in Picea orientalis. This short note describes how watering after lifting and exposure before planting affect the water potential, growth and survival of Oriental spruce transplants.

\section{Experimental treatments}

The study was conducted at "Of Forest Nursery" located $40^{\circ} 59^{\prime} 03^{\prime \prime} \mathrm{N}, 40^{\circ} 20^{\prime} 19^{\prime \prime} \mathrm{E}$ in northeast Anatolia. Study areas were about $5 \mathrm{~m}$ above sea level and located on acidic soils $(\mathrm{pH}=5.3)$ with sandy loam texture. Trials were set up with 4-year-old transplants of Picea orientalis from the provenance of Cataldere-Maden as three replications in a randomized block design; that is, there were 360 plants per treatment (120 plants per block). The experiments were established during 3 days. Thus, the first transplants were randomly lifted on 28 March 1990, and utilized in Treatments IV and VI. Likewise, 50 samples from the transplants were randomly picked out to measure the major morphological properties of stocks. Treatments I and II were established with stocks lifted on 30 March 1990 . The transplants to be used in Treatments III and $\checkmark$ were lifted on 2 April 1990. After lifting, a part of the transplants were immediately moisturized using a watering can, and all were then kept together in moist conditions in cloth sacks, after pruning the roots to a 20 $\mathrm{cm}$ length.

A part of the watered transplants were promptly planted (Treatment I), whereas the others were first placed on the ground for air drying for $60 \mathrm{~min}$, and then planted (Treatment II). The unwatered transplants, however, were subjected to drought on the ground for $0,15,30$ and 60 min (Treatments III, IV and V, respectively). A part of the unwatered transplants treated for $60 \mathrm{~min}$ utes were also moisturized using a watering can just before planting (Treatment $\mathrm{VI}$ ). The exposure was conducted between 11:30 and 14:30 in favorable conditions, under partially cloudy skies with no wind. Air temperature and relative humidity on the ground were measured during exposure, and shoot water potentials were measured at the 5 shoot samples from each treatment by the use of the pressure chamber technique (table I). The treated seedlings were planted in the nursery at about $15 \times 20 \mathrm{~cm}$ spacing into $25 \mathrm{~cm}$ deep planting holes.

\section{Plant performance parameters}

At the end of the first growing season after planting, the rates of survival and terminal shoots were first defined, and major parameters of plant performance were measured on 90 plants from each treatment (table II). Relative increments of the height and dry 
Table I. Shoot water potential $\left(\Psi_{w}\right)$ of treated seedlings, air temperature (Tem) and relative humidity $(\mathrm{RH})$ on the ground during air drying treatments.

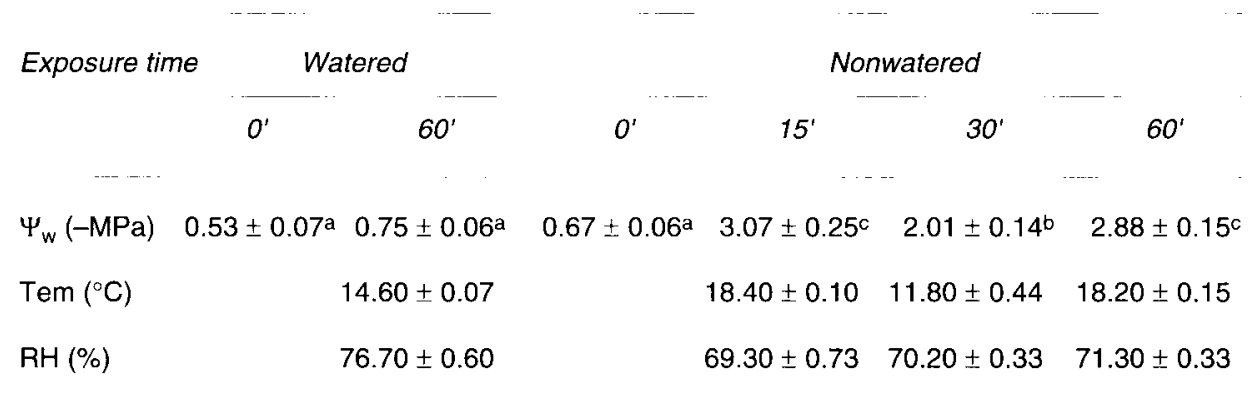

abc Means followed by the same letter are not significantly different $(P \leq 0.05)$.

Table II. Mean values of various growth parameters of the stocks in different treatments.

Properties/

Exposure time

Exposure time
Survival (\%)

TSO (\%)

Height $(\mathrm{cm})$

$\mathrm{Ht}$ increment $(\mathrm{cm})$

$\mathrm{RHI}(\%)$

Diameter ( $\mathrm{mm}$ )

Shoot dry wt $(\mathrm{g})$

Root dry wt (g)

Total dry wt (g)

RSI (\%)

RRI (\%)

RTI (\%)

\section{Watered}

$0^{\prime} \quad 60^{\prime}$

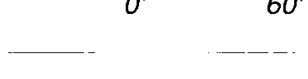

$0.99^{a} \quad 1.00^{a}$

$0.99^{\mathrm{a}} \quad 0.99^{\mathrm{ab}}$

$24.00^{\mathrm{a}}$

$5.10^{\mathrm{ab}}$

$0.27^{\mathrm{ab}}$

$8.80^{\mathrm{ab}}$

$17.10^{\mathrm{a}}$

$5.28^{\mathrm{a}}$

$2.38^{\mathrm{ab}}$

$0.74^{\mathrm{a}}$

$0.40^{\mathrm{b}}$

$0.64^{\mathrm{ab}}$ $22.60^{a}$

$5.70^{\mathrm{a}}$

$0.31^{\mathrm{a}}$

$9.10^{\mathrm{a}}$

$16.27^{a}$

$8.12^{\mathrm{b}}$

$24.39^{a}$

$0.65^{a}$

$1.15^{\mathrm{a}}$

$0.79^{\mathrm{a}}$
Nonwatered

$\begin{array}{lll}0^{\prime} & 15^{\prime} & 30^{\prime}\end{array}$

$60^{\prime}$

$\begin{array}{cccr}0^{\prime} & 15^{\prime} & 30^{\prime} & 60^{\prime} \\ & - & & \\ 0.97^{\mathrm{ab}} & 0.86^{\mathrm{b}} & 0.91^{\mathrm{b}} & 0.87^{\mathrm{b}} \\ 0.96^{\mathrm{ab}} & 0.96^{\mathrm{ab}} & 0.92^{\mathrm{b}} & 0.94^{\mathrm{b}} \\ 22.60^{\mathrm{a}} & 22.70^{\mathrm{a}} & 22.70^{\mathrm{a}} & 25.10^{\mathrm{a}} \\ 4.20^{\mathrm{bc}} & 3.70^{\mathrm{cd}} & 3.60^{\mathrm{cd}} & 3.20^{\mathrm{d}} \\ 0.23^{\mathrm{bc}} & 0.20^{\mathrm{cd}} & 0.19^{\mathrm{cd}} & 0.16^{\mathrm{d}} \\ 8.00^{\mathrm{b}} & 8.00^{\mathrm{b}} & 7.90^{\mathrm{b}} & 8.20^{\mathrm{b}} \\ 15.13^{\mathrm{a}} & 14.02^{\mathrm{a}} & 13.32^{\mathrm{a}} & 13.08^{\mathrm{a}} \\ 3.96^{\mathrm{c}} & 4.21^{\mathrm{ac}} & 3.75^{\mathrm{c}} & 3.64^{\mathrm{c}} \\ 19.09^{\mathrm{bc}} & 18.23^{\mathrm{bc}} & 17.07^{\mathrm{c}} & 16.72^{\mathrm{c}} \\ 0.54^{\mathrm{a}} & 0.42^{\mathrm{a}} & 0.35^{\mathrm{a}} & 0.33^{\mathrm{a}} \\ 0.14^{\mathrm{c}} & 0.24^{\mathrm{bc}} & 0.08^{\mathrm{c}} & 0.03^{\mathrm{c}} \\ 0.43^{\mathrm{bc}} & 0.38^{\mathrm{bc}} & 0.28^{\mathrm{c}} & 0.25^{\mathrm{c}}\end{array}$

TSO: terminal shoot occurrence; RHI: relative height increment; RSI: relative shoot dry weight increment; RRI: relative root dry weight increment; RTI: relative total dry weight increment. Means for a given parameter differ significantly $(P \leq 0.05)$ when followed by a different letter.

weight of transplants were then calculated. Proportional data were transformed to carry out ANOVA using the Arcsin $(P)^{1 / 2}$ method. Relative increment data were also transformed, multiplying with the mean values determined on 4-year-old transplants (Kalipsiz, 1981). Statistical analysis was carried out on the data using the randomized blocks ANOVA and Duncan's multiple range test at the probability level of $\leq 0.05$ (table II). 


\section{RESULTS AND DISCUSSION}

Average shoot water potential measured after Treatments ranged from -0.53 to $-3.07 \mathrm{MPa}$. There were no marked differences between Treatments I, II and III, but differences between the others were statistically significant at the least $P \leq 0.05$ confidence level. The same results were determined for the growth parameters of transplants, except for survival and the rate of terminal shoot occurrence. Best water potential $(-0.53$ and -0.75 $\mathrm{MPa}$ ), survival (99 and $1.00 \%$ ) and growth were obtained from transplants watered after lifting. In these seedlings, exposure to ambient conditions particularly stimulated root growth. Transplants in Treatment II gave a higher root increment $(1.15 \%)$ than saplings in all the remaining treatments (table II).

With unwatered transplants, however, shoot water potential $\left(\Psi_{w}\right)$ decreased, depending on high temperature and on low relative humidity during air drying. Thus, $\Psi_{w}$ in Treatment IV was lower than in Treatments $\mathrm{V}$ or VI (table I). Hence, both the survival and relative increment of height or dry weight declined significantly, as $\Psi_{w}$ diminished, but the rate of terminal shoot decreased only slightly (table II).

Results from this study indicate that performance of the Picea orientalis transplants watered after lifting differed markedly from unwatered saplings of the same species, and with watered transplants air drying before planting for 60 min stimulate root growth. When considering the results of some similar studies, this is not a surprising result. Thus, Cleary and Zaerr (1980) suggest that the bare-root seedlings of the Douglas fir and the ponderosa pine should have a water potential of greater than -0.5 MPa in order to avoid low survival and poor growth. The same results have also been established for radiata pine stocks (Rook and Menzies, 1981). Likewise, for the Sitka spruce transplants, Coutts (1981) emphasizes that "Exposure of the root caused a faster decrease in fine root moisture content than exposure of the shoot". In loblolly pine as well, survival, height and root growth potential significantly decreased as exposure time before planting was extended (Feret et al, 1985). Balneaves (1987) reported, however, that root growth capacity of macrocarpa seedlings was not affected by the length of root exposure.

In the present study, transplants were not washed after lifting or before drying treatments; that is, transplants had soil or soil particles around their root systems, so that fine roots probably did not suffer large-scale damage during exposure. Thus, shoot water potential in Treatment II was reduced to only $-0.75 \mathrm{MPa}$ since watering after lifting had increased shoot and root water potentials and prevented water losses during handling. Note that the shoot water potential level is in agreement with ideal water stress not having a limiting factor for physiological processes (Cleary and Zaerr, 1984).

In conclusion, water stress which does not limit the physiological processes and does not destroy the fine roots on a largescale has probably particularly stimulated the root growth. The planting success of the transplants in Treatment II should not be rejected, considering that if the water potential is sufficient, fine roots would not suffer significant damage by drying treatment under the auspices of soil around the root system. Even root growth may be promoted by subjecting them to drought, or short-term exposure may not affect the root growth of Oriental spruce stocks as determined in macrocarpa seedlings (Balneaves, 1987). Hence, new studies must be conducted in the Oriental spruce.

\section{REFERENCES}

Balneaves JM (1987) Root growth capacity of Cupresus macrocarpa and Pinus radiata seedlings. NZ Forestry 8 
Cleary BD, Zaerr JB (1980) Pressure chamber techniques for monitoring and evaluating seedling water status. NZ J For Sci 10, 133-141

Cleary BD, Zaerr JB (1984) Guidelines for measuring plant moisture stress with a pressure chamber. PMS Instrument $\mathrm{Co}$, Corvallis, OR, USA

Coutts MP (1981) Effects of root or shoot exposure before planting on the water relations, growth, and survival of Sitka spruce. Can J For Res 11, 703-709

Feret PP, Kreh RE, Mulligan C (1985) Effects of air drying on survival, height, and root growth potential of lobloliy pine seedlings. South J App/ For $9,125-$ 128

Kalipsiz A (1981) Statistical methods [In Turkish]. Publication of Forest Faculty of Istanbul University, Issue no $2837 / 294,558$, Istanbul, Turkey
Menzies MI (1981) Puddling and water dipping of root system - a review. In: Forest nursery and establishment practice in New Zealand. FRI Symposium no 22, Part 1, Nursery Practice, March 23-27, 1981 (CGR Chavasse, ed), New Zealand Forest Service, 153159

Rook DA, Menzies MI (1981) Methods of determining physiological quality of planting stock. In: Forest nursery and establishment practice in New Zealand, FRI Symposium no 22, Part 1, Nursery Practice, March 23-27, 1981 (CGR Chavasse, ed), New Zealand Forest Service, 159-169

Sharpe AL, Mason WL, Howes REJ (1990) Early forest performance of roughly handled Sitka spruce and Douglas fir of different plant types. Scott For 44, 257265 